\title{
Study on Althusser's Theory of Ideology
}

\author{
Lei Zhang ${ }^{*}$ \\ ${ }^{1}$ School of Marxism, Jiangsu University, major of Marxist Philosophy, Zhenjiang, China \\ * Lei Zhang, E-mail: 1421532947@qq.com
}

Received: March 1, 2017

doi:10.22158/wjer.v4n2p274
Accepted: March 10, 2017

Online Published: March 13, 2017

URL: http://dx.doi.org/10.22158/wjer.v4n2p274

\begin{abstract}
Althusser is a representative of the structuralism of western Marxism, and his theory of ideology holds a prominent position in philosophical theories. Firstly this paper starts from the overall theory of Althusser to probe into the source and course of his theory of ideology; secondly this paper introduces the main content of Althusser's theory of ideology, which includes the characteristics of ideology, ideology and science, ideological state apparatus and ideological interpellation subject; thirdly employing basic viewpoints of Marxism and referring to foreign and domestic research results, this paper conducts analysis and evaluation on Althusser's theory of ideology to dig into its in-depth theoretical connotation and value and to apply the beneficial elements into Chinese ideological construction.
\end{abstract}

\section{Keywords}

ideology, subject interpellation, ideological state apparatus

\section{Introduction}

The concept of "ideology" derives from Antoine Destutt de Tracy, but originally speaking it was presented by Bacon; later through flexural and complex development and course, it has been given multiple meanings. Marx is the first one to expose the essence of ideology. As a successor and developer of Marxist theory, on the basis of Marx's theory of ideology, Althusser has conducted pioneering researches on ideology through employing the emerging theoretical method in the west at that time, and the influence was phenomenal and global.

\section{The Source and Course of the Thought of Althusser's Theory of Ideology}

Althusser's theory of ideology did not just come out of thin air; it has its source and course of the thought. In general its source and course mainly include four aspects, which are Marx's theory of ideology, Bachelard's historical epistemology, Lacan's philosophy of mind and Gramsci's thought.

Marx's Theory of Ideology. The leading origin of the thought of Althusser's theory of ideology is Marx's theory of ideology. Firstly for Marx, ideology refers to "various emotions, visions, thinking 
modes and views of life". In the entire social structure, ideology belongs to the ideal superstructure and fundamentally it is restricted to social production and economic structure as well as to the superstructure of law and politics. Althusser considers that "ideology is a representation of the imaginative relations between an individual and his reality", same as Marx who thinks that ideology is a coalition of reality and falsehood. Meanwhile Althusser's stress on the significance of ideology in the ideological system of state apparatus is in accordance with the thought of Marx.

Bachelard's Historical Epistemology. Althusser's viewpoints about ideology and science are inspired by Bachelard's historical epistemology. Bachelard considers that science, rising from the fights against "the conatus of human spirit", has two major characteristics. Firstly synchronically speaking scientific cognition is not the opposite of knowledge, instead the opposite of the stubborn web of fallacy. Secondly diachronically speaking, there is no way that the history of science is a continuous process of knowledge accumulation, which has to be achieved through abandoning and replacing early-stage concepts. These basic viewpoints of Bachelard are clearly presented in Althusser's discourse about ideology and science.

Lacan's Philosophy of Mind. The most preeminent characteristic of Althusser's theory of ideology is the discourse about the concrete mechanism acting on individuals, namely the ideological interpellation theory, which mainly is a result of referring to Lacan's philosophy of mind. Lacan is the first one to declare the death of "I" as the subject of an individual. As Lacan considers the formation of "ego" of an individual rises from a catabolic and coercive self-identification. The first is alienated identification of the mirror image, which is also the first step for "ego" to become "non-ego". The second is the kill of language towards human in the symbolic stage, meaning an individual being enslaved to approve a symbol. As Lacan sees, at present "the social structure is symbolic". In this kingdom with symbolic order, human is being governed violently, and the human nature has become the summation of the symbolic interpellation relations of each individual in his symbolic world. Such a pseudo-subjectivity theory is the very fundamental basis of Althusser's ideological criticism.

Gramsci's thought. The characteristic of Gramsci's thought and its influence on Althusser mainly lie in his stress on the existence form of substance that is greatly emphasized by Althusser. Gramsci has put forward a formula: "state = political society + civil society; as he considers state is a leadership on the armor of repressiveness". Therefore, if the proletarian revolution wants to succeed, it has to obtain leadership in two aspects, one is the leadership in "politics" and the other is the leadership in "culture". Althusser highly appraises Gramsci's ingenuity, considering that he has presented a new "surprising" concept of state. Therefore, Althusser's theory of ideological state apparatus is a conscious systematization of Gramsci's theory of civil society. 


\section{Connotation of Althusser's Theory of Ideology}

\subsection{Characteristics of Ideology}

Firstly ideology is a structure of unconsciousness. Althusser considers that ideology is a representational system; under most circumstances they are images and sometimes they are concepts. It can be said that ideology is not consciousness in opposition to existence, instead the existence and the human world itself.

Secondly ideology is an organic component of the social totality. "The human society cannot live without these particular social formations and all sorts of representational systems of ideology. The human society secretes ideology as the air it breathes and the essential part of historical life". Althusser believes that ideology will not disappear in the world, and there will be ideology even in the communist society.

Thirdly ideology has no history. In Althusser's opinion, concrete ideology has history, while general ideology, as an essential element depended upon by concrete ideology, has no history. On the one hand, he considers that concrete ideology has its own history, although ultimately it is decided by class struggles. On the other hand he considers that general ideology with no history is said from the absolute positive perspective.

Fourthly ideology has a substantial existence, and the state apparatus and practices become the carriers of ideology. "For an individual subject (a certain individual), the existence of his concepts is substantial, of which the significance is that his concepts are his substantial actions inserted with substantial practices that are subject to substantial conventions defined by ideological state apparatus of the substance, while the concepts of the subject are from those apparatuses". Therefore, the ultimate result is that "concept" is gone, and new terms of "practice, convention and ideological apparatus" rise.

\subsection{Ideology and Science}

Most of Althusser's discourse about ideology is mainly developed in the relations between ideology and science.

Firstly the functions of ideology and that of science are different. In ideology functions of practice and society prevail over those of theories, while science mainly undertakes theoretical functions. Ideology mainly adjusts the experiential relations between human and the conditions of existence for people to better adapt themselves to, and it does not provide cognition of the world. Science provides people with cognition of the reality, which is the real knowledge. In addition, science is not transcendence of ideology. Moreover, to survive and develop, science has to struggle with ideology persistently. At last ideology and science follow different cognition paths. The cognitive process of science is from abstract to concrete, not adversely.

\subsection{Ideological State Apparatus}

"Ideological state apparatus" is a new concept presented by Althusser in Ideology and Ideological State Apparatus. Althusser considers that a state includes not only repressive state apparatus, but also ideological state apparatus, and repressive state apparatus mainly works through ideology. How to work 
is the essential difference between repressive state apparatus and ideological state apparatus.

\subsection{Ideological Interpellation Subject}

Althusser's viewpoint in summation about ideology and subject is the ideological interpellation subject. As Althusser puts it that "If it was not for the subject and for the concrete subject, there would be no ideology", because on the one hand the existence of ideology is for the subject and on the other hand ideology needs the subject to exist, meaning that ideology exist upon the category and functions of the subject, and the category of the subject is an essential component of the total ideology.

Althusser considers that ideology is forced upon people as an unconscious structure; it is a substantial existence, composed of a series of institutions and corresponding substantial practices. However, how does ideological state apparatus govern people? Althusser leads to the core of his theory of ideology, which is interpellating the individual as the subject. In the ideological interpellation, the subject is a component of ideology, through which it cognizes itself. Then what is the real subject? Althusser believes that it is the relations of production, which is an absolute subject that relying on the ideological interpellation puts everyone in his position designated by social production as the executor and undertaker of the function of production of the relations of production.

It can be seen from the above social historical background and the source and course of the thought of Althusser's theory of ideology, Althusser's theory of ideology is not an independent and completed theoretical structure, rather it is connected with and supported by Althusser's other philosophical thoughts, and together they constitute the overall Althusser's thought.

\section{Enlightenment of Althusser's Theory of Ideology for Chinese Ideological Construction}

Althusser's opinion about the theory of ideology is unique, serving as a link between the past and the future during the development process of the theory of ideology since it has inherited and developed the theories of predecessors; it not only has started a brand new perspective in the ways of analyzing Marxist texts, but also sustains creation and development in its content.

Although Althusser's theory of ideology has its positive meaning, there are limitations. While emphasizing on the ideological interpellation subject and constructing the subject, the subjectivity of human is dispelled and the essential attribute of human is neglected, leading to human beclouded in the vortex of ideology. In the discourse of Marx's anti-humanism, the infiltration between ideology and science is neglected and the relations between the two are cut apart. Also there are contradictions in Althusser's discourse about ideology itself having no history. We need to look on the positive meaning and limitations of Althusser's theory of ideology with rationality, and to draw elements that are beneficial to Chinese ideological construction.

Firstly the essential function of ideology is to achieve the reproduction of the relations of production. From this perspective, during the process of constructing socialist ideology, China needs to hold onto the essence, meaning emphasizing on the reproduction of the socialist productivity and the relations of production. According to Althusser's understanding and from his theory, we can find that during the 
process of socialist modernization it also needs the reproduction of the productivity and the relations of production to provide basic conditions for ideology to work. The ideological state apparatus put forward by him is a basic element to ensure the reproduction of the relations of production. Therefore during the process of the reproduction of socialist relations of production, we need to depend on multiple ideological state apparatuses, such as laws, schools and churches for assurance.

Secondly during the process of ideological construction, China needs to emphasize the significance of ideological apparatuses like school and family. On the one hand school can develop a large number of outstanding labor forces for the state construction; on the other hand it can propagate and promote the socialist core value system. Meanwhile, school is where ideas exchange and sparkles arise, playing a vital role in eliminating the false and retaining the true and discarding the dross and selecting the essential during the socialist ideological construction. In addition the influence of family needs to be taken seriously because parents are the first teachers for children and their behaviors and manners have lifelong influence on children; therefore the socialist core value system can be well promoted through family, thus children's sense of patriotism can be cultivated along with traditional Chinese virtue and certain moral accomplishment.

At last, from the limitation of Althusser's theory, which is the dispelled subjectivity, it can be seen that during the socialist modernization construction, the subjectivity of individuals has to be ensured. China has always been following the people-oriented strategy and people are the root for the state. Ideology interpellates people as the subject, and Althusser has only seen the submission and obedience of the subject while their initiative is neglected; that is what we need to be cautious about. Therefore, China needs to hold onto the people-oriented strategy. From the perspective of economic construction, it needs to strive to develop the productivity and to provide reliable material insurance for the subjectivity construction of human. From the perspective of politics, it has to hold onto the law-based governance, ensure people's legitimate rights, and ensure that people can fully enjoy a stable position where they are their own masters. From the perspective of thought and culture, taking Marxism and Leninism, Mao Zedong Thoughts, Deng Xiaoping Theory and the important thought of the "Three Representatives" as the guiding thought, it needs constantly connecting theories with practice, manage to advance with times, create advanced socialist culture, and provide basic cultural assurance for the subjectivity of people.

\section{References}

Jin, Y. M. (2012). On the Evolution of Althusser's Theory of Ideology and Its Influence on Contemporary Ideological Trend. Shandong Social Sciences, 1, 19-23, 28.

Lu, Y. (2015). On Althusser's Theory of Ideology. Journal of Renmin University of China, V29(1), 133-139.

Yu, W. J. (2004). New Exploration on Althusser's Theory of Ideology. Jiangxi Social Sciences, 3, 26-31. 
Zhang, Y. B. (2002). Althusser: Ideological Theory and Lacan. Study and Exploration, 4, 1-5.

Zhang, Y. B. (2002). Reinterpretation of Althusser. Social Sciences in Nanjing, 4, 7-9. 